\title{
Omani Students' Attitudes towards EFL Reading between School and Univer- sity Foundation Programs: A bridge or a gap?
}

Fawzia A. Al Seyabi* \& Kamla S. Al Amri

Sultan Qaboos University, Sultanate of Oman

Received: 15/5/2016

Accepted: 30/6/2016

\begin{abstract}
Using questionnaires administered to 1114 school students and 317 university foundation program students, the study aims to investigate students' attitudes towards English as a foreign language (EFL) reading in the two educational contexts: post-basic schools and university foundation programs. The study also explores the extent to which students feel school has prepared them to the reading requirements of their university foundation programs. The study revealed that there were significant differences between school students and university foundation program students in the cognitive and affective dimensions of reading attitude but there were no significant differences in behavioural attitudes. Students also believed that they could not transfer the reading skills they acquired at post-basic education to the English classes at the foundation program because reading is different in the two educational contexts. The study makes a number of pedagogic and administrative recommendations to help bridge the gap between EFL reading in schools and universities.
\end{abstract}

Keywords: EFL reading, attitude, foundation programs, post-basic education, Oman.

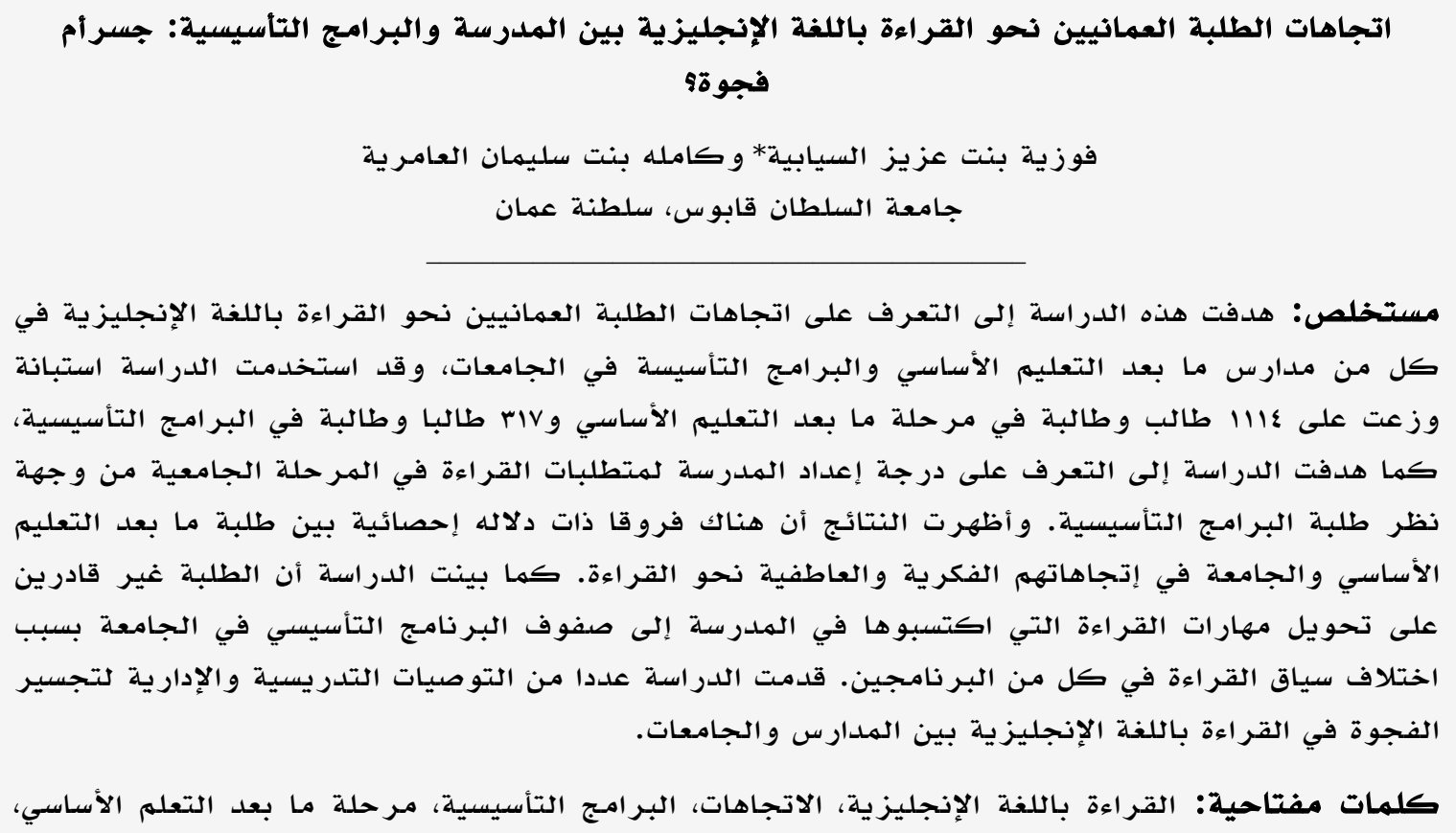


Reading occupies a prominent place in EFL programs across the world and one can hardly find a language course where developing students' reading skills is not at the forefront of policy makers' attention. Governments and private educational institutions spend a lot of time, money and effort to improve their reading programs and help students acquire a wide range of reading skills that are believed to be indispensible for their present and future academic success. Despite these efforts, there have been a number of observations about students' reluctance to read and about the lack of a reading culture that dominates among students (Al Ajmi, 2003; O'Sullivan, 2004; Al Khamisi, 2014). Students do not seem to grasp the full potential that reading has in expanding their knowledge and shaping their personalities especially when they see that they can pass exams without doing much reading. It is not uncommon to hear complaints from college teachers and professors about their students' reading levels. Concerns are often raised about what schools are doing in order to help students acquire not only the necessary reading skills but also positive attitudes to read (Teale \& Lewis, 1981; Torenbeek, Jansen \& Hofman, 2011; Briggs, Clark, \& Hall, 2012).

The transition from school to college requires transition of a whole range of skills and abilities; perhaps reading tops these given that most college courses and their assignments are grounded on reading. According to Jolliffe and Harl (2008), the move from school to college entails "a transition to different types of reading, different amounts of reading and different approaches to success with reading" ( $p$. 615). We believe that understanding students' perceptions of reading in both school and college settings and their attitudes towards reading is a key to facilitating this schooluniversity transition and helping students with their academic achievements in both contexts.

Understanding reading requires attention to the emotional and affective aspects related to reading and learning (Downing, 1982). In spite of this importance, compared with research on the cognitive domain, researchers paid less attention to emotional aspects of learning (Yamashita, 2004). Students' attitudes towards reading is one affective area that is a key to understanding students' reading behaviour.
Some research done on reading attitudes in EFL contexts investigated its different facets/components and has more specifically set to explore its connection to foreign language learning. This link is especially important in contexts where students have limited resources to exposure to the language in its spoken form and have to rely on written texts to assimilate the language and learn it best. Most research has established a connection between having positive attitudes towards reading and improved reading performance (Al Khamisi, 2014; Parker, 2004; Elley \& Mangubha, 1983). This has been recognized by some as a twoway relationship: positive attitudes can increase chances of better reading performance; the latter can similarly get students to develop positive reading attitudes.

In sum, the present study is set to explore Omani students' attitudes towards EFL reading in two educational contexts: their last two years of school (grades 11 and 12) and their first year of college study as they enrol in English foundation programs (FP). Some of the questions the paper aims to answer are: How do students in their final years of school in Oman view reading in their English classes? To what extent do they perceive themselves to be good readers? Do students in the university foundation programs hold similar views? Other questions that the paper aims to explore are: To what extent do students feel school has prepared them to the reading requirements of their foundation programs at university and to what extent they feel they can transfer the reading skills they acquired at school to their new university context.

\section{Review of the literature}

A number of definitions of reading attitude can be found in the literature. Smith (1990, p. 215) defines it as "a state of mind, accompanied by feelings and emotions that make reading more or less probable". Parker (2004, p. 57) cited Alexander and Filler (1976) who viewed reading attitude as "a system of feelings" and as something that could cause learners to approach or avoid a reading situation. It can also affect the amount of voluntary reading that students do (Partin \& Hendricks, 2002).

Most research on reading attitude views "attitude" as a complex construct. A number of reasons can account for this complexity. For 
example, the formation and development of attitude may get affected by different factors and it can evolve or "dissolve" over time. Studies point to a number of factors that can affect the formation of a positive reading attitude. Partin and Hendricks (2002) explain that secondary school students who regard reading as an attractive activity and enjoy doing it have identified positive role models such as parents, siblings and friends as responsible for their love of reading. Kubis (1996), cited in Partin and Hendricks (2002), mentions other factors such as going through a significant event that created a strong positive feeling towards reading. Examples are being read to regularly as children and having the chance to visit public libraries.

Another significant factor that could affect the shaping of attitude is the teaching practices that a teacher uses in class. McRae and Guthrie (2015) explain that while reading widely and frequently is important, it is not adequate. Providing contextual motivational support in class could play a more significant role in enhancing a more positive attitude towards reading. When planning and implementing reading instruction in class, teachers need to consider students' emotions toward reading topics and reading activities. Failure to do so would impact not only a student's view of reading but could also taint further reading experiences (Fountas \& Pinnell, 2012).

Another reason that can account for the complexity of attitude is that it has multiple variables. Researchers on reading attitude agree that it can be defined by three components:

1. The cognitive component which includes personal and evaluative beliefs. It can also refer to thoughts and attributes that people associate with reading.

2. The affective component, which comprises an individual's feelings and emotions towards reading material and/or the reading process.

3. The behavioral component which covers behaviours and behavioural intentions. This can also include past experiences regarding reading.

Research on attitude indicates that although these three components are different, they are not completely independent of each other (Maio \& Haddock, 2009). They could interrelate and the degree of presence and strength of each one of them could vary from one individual to another. A number of studies have in fact reported that students generally tend to think of themselves as "good" readers. A study that investigated primary students reading attitudes and self-concept in different countries revealed that internationally, students in primary classes seem to view themselves as good or at least moderately good readers (Mullis, Martin, Kennedy, \& Foy, 2007). Similarly, a preliminary investigation of students' perceptions towards reading in one specific FP context in Oman was carried out as part of the present study (Tuzlokova, AlSeyabi, Al-Rawahi, \& Al-Owasi, 2014). Findings of this investigation revealed that almost two thirds of the students felt they were good at reading and that they often used it as a tool to improve their English language. Overall, students had positive attitudes towards reading.

Some models of reading attitude, however, warn that positive reading attitudes do not necessarily lead to active reading behaviour. Mathewson (2004), for example, asserted that a learner's attitude might be positive but he/she lacks the intention to read or continue reading. The latter construct, one's intention to $\mathrm{read} /$ continue reading can be influenced by a wide range of factors such as motivation and the availability of reading material and resources.

There are very few studies that have looked closely at reading attitudes and their manner of development over time. Most of these were conducted in L1 contexts. For example, Smith (1990) conducted a longitudinal investigation of reading attitude development from childhood to adulthood and followed individuals over nearly 40 years. One of her findings was that the attitudes shaped in early adulthood, that is, around the time students finished high school - compared to childhood- can account for one third of the variance in adults' reading attitude. Other studies indicated that even though children tend to have relatively positive attitudes towards both recreational and school-based reading, these unfortunately tend to drop when students reach higher grades in their schools (Kush \& Watkins, 2010). In his review of attitudinal research, McKenna (2008) observes that most studies report that reading attitude tend to worsen over time. One possible reason cited by him is that as children grow up, more leisure options 
become available to them and these tend to compete with reading.

Although the present study is not longitudinal as it is not based on investigating attitudes of the same group of students as they move across two consecutive educational contexts, we still believe it can provide us with insights on how students in both post-basic schools and foundation programs in Oman view reading in their English class and the factors that affect their attitudes. This could in turn help us gain a better understanding of reading and whether the reading difficulties that are often reported could at least be partially attributed to students' attitudes towards reading.

\section{Method}

\section{Population and sample}

With regard to post-basic school students, the population of the study comprised all students doing post-basic education (grades 11 and 12) in the three educational governorates involved in the study in the academic year 2013-2014. These were Muscat, Batinah South and Dhakeleya. With the help of English teachers and senior English teachers, questionnaires were distributed to intact classes from six randomly chosen schools from each governorate.

As for university foundation programs, the population comprised students doing the foundation program in the three universities: Sultan Qaboos University, Nizwa University and Sohar University. The questionnaire was distributed by teachers to intact classes from the different levels of the foundation programs in the three universities (see Table 1 that shows the distribution of students from each group and in each governorate for more information).

Table 1

Distribution of students in post-basic schools and foundation

\begin{tabular}{lrll}
\multicolumn{3}{c}{ programs } \\
\hline Schools/Governorate & Count & University & Count \\
\hline Muscat & 22 & $\begin{array}{l}\text { Sultan Qaboos } \\
\text { University (Mus- }\end{array}$ & 134 \\
& 9 & $\begin{array}{l}\text { cat) } \\
\text { Sohar University }\end{array}$ & 96 \\
Batinah South & 27 & $\begin{array}{l}\text { (Batinah) } \\
\text { Nizwa University }\end{array}$ & 87 \\
Dhakeleya & 1 & $\begin{array}{l}\text { (Dhakeleya) } \\
\text { Total }\end{array}$ & 317 \\
Total & 61 & & \\
& 4 & & \\
\hline
\end{tabular}

\section{Instrumentation}

To investigate students' perceptions of different aspects pertinent to their EFL reading in grades 11 and 12 and later in the foundation program, a questionnaire in the English language was developed. The questionnaire was validated by a jury comprising faculty members from the College of Education and College of Arts at Sultan Qaboos University as well as curriculum experts from the Ministry of Education in Oman. After establishing its validity, the questionnaire was translated into Arabic, the students' mother language and administered to school and university students during class time. The reliability of the questionnaire was also established using Cronbach's alpha and was found to be .68, which is considered an acceptable level of reliability.

Data presented and discussed in the present study were obtained from one scale on reading attitudes included in both questionnaires: school students and foundation program students. The scale used a five point Lickert scale that ranged from "strongly agree" to "strongly disagree". In this subscale, students were asked to indicate to what extent they agreed or disagreed with a list of points reflecting various issues that examined their attitudes towards reading.

The questionnaire included items that targeted the three attitude components as identified in the literature: The cognitive component looked at students' use of reading as a tool to improve their English language, and their beliefs of the relative importance of the reading skill compared with other skill areas. As for the behavioural dimension of attitude, this was addressed through items that looked at the amount of preparation students had for their reading classes, and the amount of extensive reading they did. Items addressing the affective component of attitude included value of reading to one's self, students' evaluation of their ability and their enjoyment of reading. There were also a few items that investigated students' perceptions of the role that their families and friends played in encouraging them to read as well as the way they felt about teachers' teaching methods of the reading skill.

The questionnaire for foundation program students included a few extra items that sought to investigate FP students' views on whether reading at school is different from reading at the university, and the extent to 
which they felt school has prepared them for the reading demands of the university. Another item was concerned with students' ability to transfer the reading skills they learned at school to their English class at the university foundation programs. SPSS was used to analyse data gathered from the questionnaires.

\section{Results and discussion}

\section{Students' attitudes towards EFL reading}

Table 2 shows the means and standard deviations for the three types of attitudes: cognitive, affective and behavioural and for the individual items underneath each type. It also displays t-test results for differences between students in post-basic schools and students in foundation programs in the different types of their attitudes towards reading.

Based on the results displayed in Table 2, there were significant differences $(p<.01)$ between school students and FP students in two dimensions of their attitudes towards EFL reading: the cognitive dimension and the affective dimension. In all individual items of the affective attitudes sub-scale, FP students seemed to get higher mean scores than school students. To start with, foundation program students reported the highest scored mean in the whole questionnaire, which was (4.48) in the first statement, "[We] like learning the English language", compared to the mean score of 4.26 among school learners. With regard to reading, students expressed their preference towards reading and discussing passages of English texts in the English lesson. Although not significant, this finding still shows a higher mean score with foundation program students than school ones. Students have also affectively expressed that they "enjoy reading other texts besides the textbooks such as stories and newspapers". University students displayed more affinity and high attitude towards this practice thanks to their responsibility and maturity maybe. Another possible reason is that reading material as well as access to reading resources is more widely available to university students, whereas it is more confined to schoolwork and, in a few cases school libraries at the school setting. This result goes in par with what has been documented in the literature.

Table 2

T-test results for differences between post-basic school students and foundation program students in their attitudes towards EFL reading

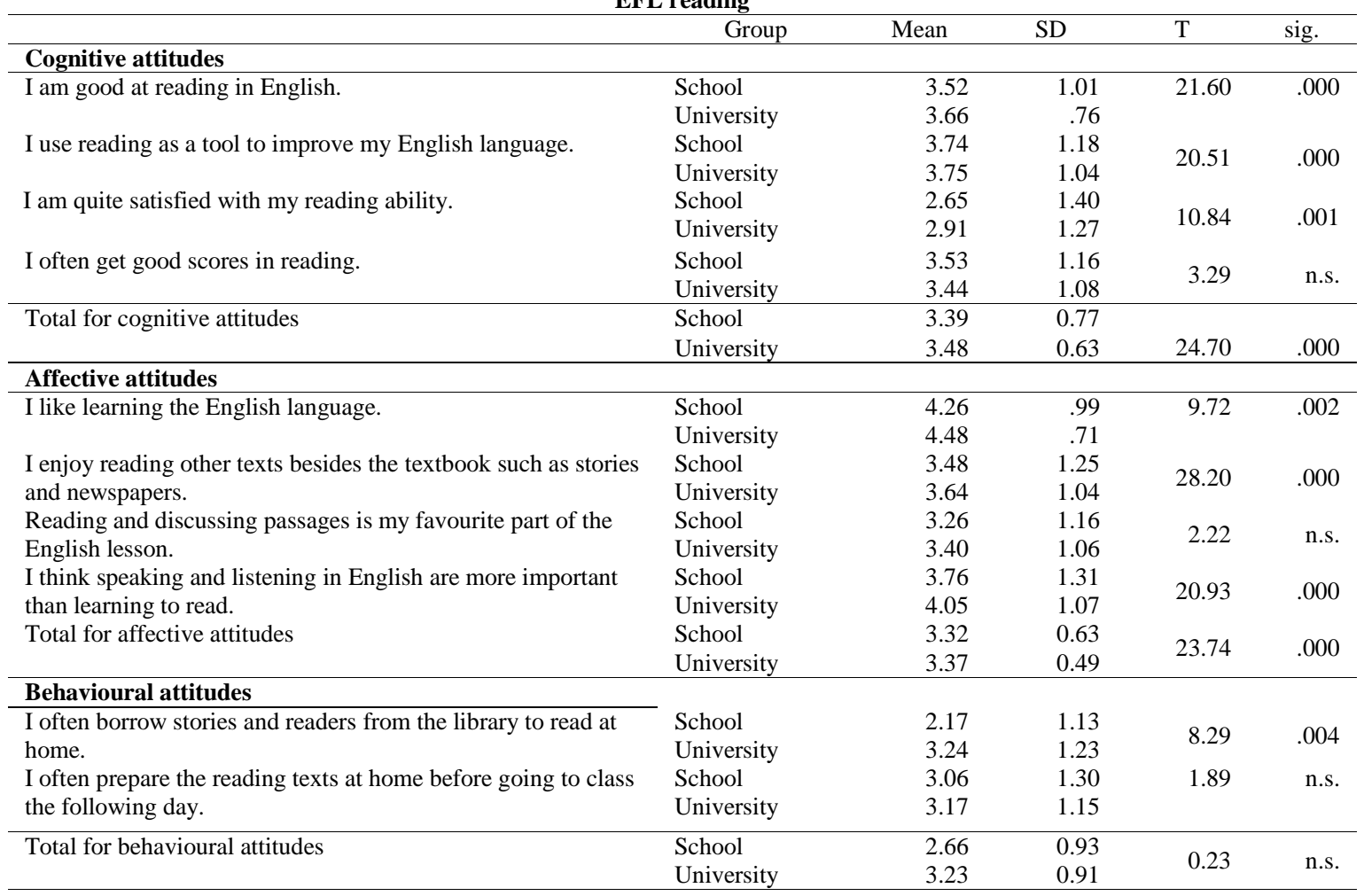


For example, Ghrib's (2003) study on attitudes toward reading in the Tunisian university context revealed that $82 \%$ of the participants had a positive attitude towards EFL reading. The study by Tuzlukova et al. (2014) on Omani university context revealed similar results.

With regard to cognitive aspects of attitude, which cover, among other things, learners' evaluative beliefs of their reading, the results revealed significant differences between school students and university FP students ( $\mathrm{p}$ $<0.05)$. University foundation program students expressed a better contentment towards their reading potentials than school students did. However, despite university students' overall positive satisfaction with their level, they still achieved low in reading (Mean = 3.44) compared to school students (Mean = 3.53) who believed they had good scores in this skill. It seems here that students come to reading classes with high motivation but less competence in dealing with and tackling reading requirements. This might be partly attributed to the fact that reading requirements in foundation programs are more demanding than school requirements and, hence, it is more likely that students get lower scores in their reading tests.

Also, related to the cognitive domain, students reported that they "often use reading as a tool to improve [their] English language". This statement showed almost a similar mean score for both school (3.74) and university (3.75) students. This reflects the students' awareness of the importance of reading as an empowering skill in the process of learning English. However, in spite of this acknowledged importance, students at the university level felt that speaking and listening in English are more important than learning to read, a result that echoes findings revealed by other studies conducted in the same university context (Al Seyabi, 1995). This could be a result of students' tendency to equate proficiency in English as a foreign language with the ability to speak it fluently.

Furthermore, mindfulness and awareness are another issue; university students tend to be more aware of the usefulness and effectiveness of extensive reading. Hence, they do a lot of outside reading. This reflects the availability of resources for students in universities and that school students lack those resources to help them with their learning. In contrast to this, school students scored the lowest mean score in this regard (2.17). More interesting is the fact that other studies confirmed this finding and that "Jordanian EFL students consider improving other language skills as more important than improving reading" (as cited by Khreisat \& Kaur (2014). Thus, stressing the value of extensive/recreational reading among students needs to be heightened (Al Seyabi \& Al Rashdi, 2016).

As stated earlier, there were no significant differences between school students and foundation program students in their behavioural attitudes towards EFL reading. Furthermore, items concerned with more behavioural aspects of reading attitude seemed to receive lower means than items examining affective and cognitive dimensions. For example, the statement investigating whether students prepared the reading texts at home before going to class received one of the lowest means among items investigating all three dimensions (3.06 for school students, and 3.17 for foundation program students). The same can be said about the statement investigating whether students borrow stories and other reading material for more extensive reading. In fact, this statement received the lowest mean among all statements by grade 11 and 12 students. While this might partly be attributed to the lack of extensive reading material, it also reflects that students in general, whether at school or at the university foundation programs, are less willing to exert effort towards actual reading, a finding that lends support, to a certain extent, to Mathewson's (2004) attitude model which states that positive reading attitudes that come in the form of enjoyment and other affective forms do not necessarily lead to active reading behaviour.

\section{Influence of family, friends and teachers}

Besides investigating the three dimensions of attitude, the present study has also looked at the influence of some variables that might affect reading attitude, namely, the role of the family, friends and teachers. Table 3 displays t-test results for differences between students in post-basic schools and students in foundation programs in their views with regard to these variables. 
Table 3

T-test results for differences between post-basic school students and foundation program students in their views of the role of family, friends and teachers

\begin{tabular}{|c|c|c|c|c|c|}
\hline Statement & Group & Mean & SD & t-value & sig. \\
\hline \multicolumn{6}{|l|}{ Role of the family } \\
\hline \multirow[t]{2}{*}{ My family encourages me to read in English. } & School & 3.87 & 1.29 & .067 & .796 \\
\hline & University & 3.87 & 1.26 & & \\
\hline \multirow{2}{*}{$\begin{array}{l}\text { We have English books and stories at home which I often } \\
\text { read in my free time. } \\
\text { Role of friends }\end{array}$} & School & 3.00 & 1.24 & 1.277 & .259 \\
\hline & University & 2.85 & 1.28 & & \\
\hline \multirow{2}{*}{$\begin{array}{l}\text { I like to read books and other texts in English because my } \\
\text { friends read a lot. }\end{array}$} & School & 2.98 & 1.28 & 0.806 & 0.369 \\
\hline & \multicolumn{4}{|c|}{ Teachers } & \\
\hline \multirow[t]{2}{*}{ My teacher uses interesting ways in teaching reading. } & School & 3.49 & 1.34 & 2.926 & 0.087 \\
\hline & University & 3.10 & 1.39 & & \\
\hline
\end{tabular}

Table 4

\begin{tabular}{|c|c|c|}
\hline \multicolumn{3}{|c|}{ Means and standard deviations of foundation program students' responses } \\
\hline Statement & Mean & SD \\
\hline Reading at the university is very different from reading at school. & 4.00 & 1.30 \\
\hline $\begin{array}{l}\text { When I came to the university, I felt that school prepared me well for the reading require- } \\
\text { ments at the foundation programs. }\end{array}$ & 2.42 & 1.33 \\
\hline $\begin{array}{l}\text { I can transfer the reading skills I learned at my secondary school to my English class at the } \\
\text { foundation programs. }\end{array}$ & 2.94 & 1.27 \\
\hline
\end{tabular}

Germane to factors, interestingly, findings revealed that the students' families play a much more important role in encouraging them to learn and read. Table 3 above reveals that there were no significant differences between both groups of students in this regard. With regard to family encouragement, both school and university students have an equal mean score of (3.87), a stronger score than the one received by the item investigating the role of friends in influencing students' reading motivation and behaviour. It is important to bear in mind that unlike thirty or forty years ago in Oman, most parents of students in their last years of school and those in their first years of university education are educated parents. University students, for example, are secondgeneration students. It is not unlikely that their parents have graduated from the same universities or at least other higher education institutions in the country. These parents realize the importance of education in general and of reading in particular as a tool to enhance their children's chances of success. This result resonates with Nickoli, Hendricks and Smith's (2003) study on home literacy environment, which reported a positive correlation between encouragement from parents as well as having access to reading material at home and positive reading attitudes. Compared with the role of the family, peer influence was found to be weaker. This was the case with both school and FP students as no significant differences were found between them with this regard. In short, the present study found that if and when students read, especially outside class, it is more likely a result of family encouragement than because of peer influence.

Another factor investigated is the teachers' ways of teaching reading in the EFL classroom. This is again an item that showed no significant differences between school students and FP students. The university FP students $($ Mean $=3.10)$ do not think that these teaching methods are as interesting as school students do (Mean $=3.49$ ). This result is a little surprising considering that there are specific reading classes for foundation programs compared with English lessons at school where reading is integrated with other skill areas. Perhaps this happens because students expect a lot from teachers at higher levels but teachers do not fully meet their students' expectations.

\section{Transferring the reading skills to university settings}

The foundation program students' version of the questionnaire has also aimed to investigate university students' views with regard to their readiness to the reading requirements in their English classes and whether they thought school prepared them well in this regard. Table 4 shows the mean and standard deviation for the items falling under this area.

When university students were asked if they could transfer the reading skills they learned at post-basic education to the English classes at the foundation programs, their responses were low with a mean score of 2.94 . One possible explanation could be illustrated in their response to another relevant statement: "Read- 
ing at the university is different from reading at school", which received a mean score of 4.0. University students have also felt that school did not prepare them well for the reading requirements of the foundation programs and that the reading they do at college is different. Although the statement does not specify what is different about reading, it is quite possible that students are referring to a wide range of aspects such as type and length of reading material as well as the teaching and learning approaches used. This emphasizes the void between the two settings and that the preparation students receive in school was not enough to equip them with the necessary skills before they attend university classes. Unfortunately, studies from various parts of the world have pointed to this "great divide" between secondary schools and higher education (Kirst \& Venezia, 2001; Jolliffe \& Harl, 2008). Kirst and Venezia (2001) describe how the lack of coordination between schools on one hand and the post secondary sector on the other impedes successful transition between the two systems and call to open more channels of communication to help bridge this gap.

\section{Implications and conclusion}

In closing remarks, this paper has contributed to the plethora of literature available that investigated EFL reading. It has specifically addressed the following questions. How do students in their final years of school in Oman view reading in their English class? What are their attitudes towards it? To what extent do they perceive themselves to be good readers? Do students in the foundation programs of their university education hold similar views? Other questions that the paper explored were: To what extent do students feel school has prepared them to the reading requirements of their foundation programs at university and to what extent do they feel they can transfer the reading skills they acquired at school to their new university context?

The study has a number of pedagogic and administrative implications. In light of the findings of this paper, there are certain aspects that need to be considered when exposing or introducing students to reading materials. For example, it is very important to incorporate class activities that highlight the value of reading and the enjoyment that can be gained from engaging with texts. In their article on how to motivate and engage students in reading, Cambria and Guthrie (2010) suggest a number of activities that teachers can adopt in reading classes across different grade levels. In as early as the elementary classroom, teachers can choose activities that aim to achieve some or all of the following aims: 1) building success by choosing reading materials that have appropriate difficulty levels 2) assuring relevance by providing materials that students must value and relate to in order to grow dedication to read; 3) fostering awareness by discussing with students the knowledge that can be gained from reading which should fuel their longer-term dedication to reading; 4) affording choices that can be as small as choosing a partner to read with, choosing a colour card to read or choosing whether to take notes or not; 5) creating relations between students and teachers which should boost students' confidence in themselves and develop their trust in teachers' support; and 6) arranging social goals by creating reading projects that call for a student's organization and persistence in reading.

Moreover, finding that the affective domain of attitude is quite strong for both groups of students is a positive sign and is a fact that should be capitalized upon. We believe that with the careful selection of teaching approach, appropriate guidance as well as the provision of suitable materials, among other things, this strong affective attitude could be turned into positive cognitive and behavioural attitudes. The behavioural attitude towards reading can also be promoted through an explicit modelling of strategic tools that students can employ while reading to boost their confidence in their reading ability, ease their apprehension and encourage them to do more reading behaviour in future. Such strategic tools can range from very easy ones such as rereading difficult parts of a text and guessing the meaning of unknown words from context to more comprehensive strategies such as relating the information read to other information presented in other contexts or to students' background knowledge (Farrell, 2001).

The cultivation of a reading culture and the promotion of reading practices in school is also another helping factor to foster reading habits. Grabe (2008) has stressed the notion that educational establishments should pre- 
pare students not only to be competent in reading but also to attain a lifelong desire for reading and learning. It is interesting to note here that Grabe did not tackle the cognitive facet of students' learning only but he also emphasized the importance of the affective domain in promoting students' reading attitudes. Among the causes behind reading weaknesses in the Arab world is that Arab EFL students lack reading practice (Mourtaga, 2005). Hence, creating a culture of healthy reading habits is very much needed at both school and university levels. Also, teachers need to stress the value of extensive reading and its importance on students' reading achievement and performance (Khreisat \& Kaur, 2014). To help achieve this, it is extremely important to equip schools and school libraries with adequate reading material and work on making them more reader-friendly (Al Seyabi \& Al Rashdi, 2016). Financial support from private companies and businesses is indispensable with this regard.

Both the learning and social community in which the student is a member play a significant role in creating and modelling a culture of reading. This role is played by parents, siblings, teachers, friends and other members of the family but it is mainly parents at home and teachers at school who are held responsible for all the beliefs and thoughts that students establish and carry with them about reading. Students need to be guided by their parents and instructed by their teachers to read in their first language and that the loving- reading habit needs to be seeded in their heads at an early age so that they can practice it later on in their lives (Ismail \& Tawalbeh, 2014).

The study's finding regarding students' inability to transfer the reading skills acquired at school to the university context is quite alarming as it points to a serious gap that exists between the two contexts. This calls for urgent communication and coordination of efforts. It is very important that educationalists from all sectors concerned, such as the Ministry of Education in Oman as well as higher education institutions work together to bring about required changes in consultations with the other end. Of particular importance is teachers' teaching approach of the reading skill. In fact, literature on school effectiveness has pointed to a positive relationship between the type of teaching approaches employed in secondary schools and students' achievement in higher education in general and their first year experience in particular (Torenbeek et al., 2011). Students' experiences at school and the way they were taught seem to have a long-term effect on their university education.

Of late, we as parents, teachers and practitioners have to enforce the skill of reading at home and in schools or universities. Not only do we have to focus on reading as a skill but we also have to care about how our students view reading and their attitudes towards it. Let us not forget that those learners are also digitally oriented and electronically minded. Hence, what might not interest them on paper alone; they can find it more intriguing on screen. To close, we opt for our future generations to acquire positive attitudes towards reading and sustainable reading skills.

\section{Acknowledgment}

The authors would like to thank and acknowledge the participation of all the students in the Post Education system in the three educational governorates: Muscat, Batinah South and Dhakeleya (Grades 11 \& 12) and the Foundation Programs students in the Sultan Qaboos University, Nizwa University and Sohar University who contributed to the completion and success of this study.

\section{References}

Al-Ajmi, S. A. (2003). Omani EFL students' perceptions of reading difficulties. Unpublished master's thesis, Sultan Qaboos University, Oman.

Al-Alawi, K. M. (1994). English as a Foreign Language in Third year Secondary Education in Oman. Unpublished doctoral dissertation, University of Bath, UK.

Al-Brashdi, B. (2002). Reading in English as a foreign language: A descriptive study on Omani university students' reading comprehension problems and strategies. Unpublished master's thesis, University of Reading, UK.

Al Khamisi, H. (2014). Gender gap in reading: The impact of reading self-efficacy beliefs on EFL reading achievement. Unpublished master's thesis, Sultan Qaboos University, Oman.

Al Said, A. (1996). A diagnostic study of the EFL reading ability of Omani secondary school students in the Muscat region. Unpublished 
master's thesis, Sultan Qaboos University, Oman.

Al-Salmi, L. (2005). Reading problems as perceived by English teachers in the Sultanate of Oman. Unpublished master's thesis. The University of Texas, El Paso, US, ProQuest, Umi Dissertations. Retrieved August 2, 2013

http://ezproxy.squ.edu.om:2062/docview /305383538.

Al Seyabi, F. (1995). Identifying the English language needs of science students in the College of Science and College of Education and Islamic Sciences at Sultan Qaboos University. Unpublished master's thesis, Sultan Qaboos University, Oman.

Al Seyabi, F., \& Al Rashdi, S. (2016). A closer look at extensive reading in Omani public schools: Current practices and teachers' perceptions. English Language Teaching, 9(8), 93-105.

Al Seyabi, F., \& Tuzlukova, V. (2015). Investigating EFL reading problems and strategies in post-basic schools and university foundation programs: A study in the Omani context. The Malaysian Journal of ELT Research, 11(2), 35-51.

Applegate, A., \& Applegate, M. (2004). The Peter effect: Reading habits and attitudes of pre-service teachers. The Reading Teacher, 57(6), 554-563.

Briggs, A., Clark, J., \& Hall, I. (2012). Building bridges: Understanding student transition to university. Quality in Higher Education. Retrieved April, 4, 2015 http://www.tandfonline.com/doi/abs/10. 1080/13538322.2011.614468\#.VhYXijtUCUk

Cahyono, B., \& Widiati, U. (2006). The teaching of EFL reading in the Indonesian context: The state of the art. TEFLIN Journal, 17(1).Retrieved June 8, 2013 http://journal.teflin.org/index.php/teflin /article/viewArticle/186.

Cambria, J., \& Guthrie, J. (2010). Motivating and engaging students in reading. The NERA Journal, 46(1), 16-30.

Downing, J. (1982). Reading-Skill or skills. The Reading Teacher, 35, 534-537.
Ediger, A. (2008). Developing strategic L2 readers by reading for authentic purposes. In Usó-Juan, E \& Martínez-Flor, A. (Eds.) Current trends in the development and teaching of the four language skills (pp. 261-279), SOLA Studies in Language Acquisition, De Gruyter.

Elley, B., \& Mangubha, F. (1983).The impact of reading on second language learning.Reading Research Quarterly, 19(1), 53-67.

Emery, H., \& Thehli, H. (2014). Teaching reading in the Omani EFL classroom: Insights from teachers. In Emery, H. \& Moore, N. (Eds.) Teaching, learning and researching reading in EFL (pp.70-87). Dubai: TESOL Arabia Publications.

Farrell, T. (2001). Teaching reading strategies: "It takes time!". Reading in a Foreign Language, 13(2), 631-646.

Foundation Programs Curricula.Retrieved April 14, 2014 http://www.squ.edu.om/Portals/28/CD U/FPEL\%20Curriculum\%20Document $\% 20$ 2012-2013.pdf.

Fountas, I., \& Pinnel, G. (2012). Guided reading: The romance and the reality. Reading Teacher, 66 (4), 268-284.

Grabe, W. (2008). Reading in a second language: Moving from theory to practice. Cambridge: Cambridge University Press.

Ghrib, E. (2003). University students' and teachers' attitudes towards an EFL reading program. TESL Reporter, 36 (1), 41-58.

Ismail, N., \& Tawalbeh, I. (2014). Effectiveness of a metacognitive reading strategies programs for improving low achieving EFL readers. International Education Studies. Canadian Center of Science and Education. Retrieved September 9, 2015 from http://dx.doi.org/105539/ies.v8n1p71

Jolliffe, D., \& Harl A. (2008). Texts of our Institutional lives: Studying the "reading transition" from high school to college: What are our students reading and why? College English, 70 ( 6), 599-617.

Khreisat, M., \& Kaur, S. (2014). English recreational reading habits of Arab Jordanian EFL tertiary students. Emerald. Retrieved 
September 9, $2015 \quad$ from www.emeraldinsight.com/1753-7983.htm.

Kirst, M., \& Venezia, A. (2001). Bridging the great divide between secondary schools and postsecondary education. Phi Delta Kappan, 83 (1): 92-97.

Kush, J., \& Watkins, M. (2010). Long-term stability of children's attitudes toward reading.The Journal of Educational Research, 89(5), 315-319. Retrieved April 29, 2015 http:/ / www.bwgriffin.com/gsu/courses/ edur9131/content/Reading_Attitudes_Kus h_Watkins_1996.pdf.

Mathewson, C. (2004). Model of attitude influence upon reading and learning to read. In R. B. Ruddell \& N. J. Unrau (Eds.) Theoretical models and processes of reading (pp.14311461). Newark, DE: International Reading Association.

McRae, A., \& Guthri, T. (2015). Teacher practices that impact reading motivation. Retrieved June 14 from http:/ / www.readingrockets.org/article/te acher-practices-impact-reading-motivation.

Maio, G., \& Haddock, G. (2009). The Psychology of attitudes and attitude change. Sage Social Psychology Programs. RetrievedJune 202015 from:

http://www.sagepub.com/upmda-

ta/29580_01_Maio_\&_Haddock_CH_01.pd f.

McKenna, M. (2008). Development of Reading Attitudes. In Verhoeven, L. \& Snow, C. (Eds.) Literacy and motivation: Reading engagement in individuals and groups (pp.124144).Taylor and Francis e-library.

Mourtaga, K. (2005). Some reading problems of Arab EFL students. Al-Aqsa University Journal, 10 (2), 1-16.

Mullis, V., Martin, M., Kennedy, A. \& Foy, P. (2007).Students' reading attitudes, selfconcept, and out of school activities.In PIRLS 2006 International Report.Literacy Study in Primary Schools in 40 Countries.TIMSS \& PIRLS International Study Center.

Nickoli, A., Hendricks, C., Hendricks, J., \& Smith, A. (2003).Understanding the relationship between attitude toward reading and home literacy environment. American Reading Forum Online Yearbook, 23.

O'Sullivan, A. (2004). Reading and Arab college students: Issues in the United Arab Emirates Higher Colleges of Technology. Paper presented at the First International Online Conference on Second and Foreign Language Teaching and Research: Beyond Borders. Retrieved February 2, 2015 from The Reading Matrix Web site: ttp://www.readingmatrix.com/conference /pp/proceedings/sullivan.pdf

Parker, C. (2004). An evaluation of student reading attitudes: Does ability affect attitude? Unpublished Master's thesis, University of North Carolina at Wilmington. USA.

Partin, K., \& Hendricks, C. (2002).The Relationship between positive adolescent attitudes toward reading and home literacy environment. Reading Horizons, 43(1), 61-84.

Seitz, L. (2010). Student attitudes toward reading: A case study. Journal of Inquiry and Action in Education, 3(2), 30-44.

Smith, C. (1990). A longitudinal investigation of reading attitude development from childhood to adulthood. The Journal of Educational Research, 83 (4), 215-219. Retrieved April 28, 2015 http:/ / coeweb.gsu.edu/coshima/EPRS855 0/articles/PDF-Lori\%20Jackson.pdf.

Teale, W., \& Lewis, R. (1981). The nature and measurement of secondary school students' attitudes toward reading.Reading Horizons, 21 (2), 94-102. Retrieved June 14 2015, http:/ / scholarworks.wmich.edu/cgi/view content.cgi? article $=2079 \&$ context $=$ reading_horizons\&seiredir $=1 \&$ referer $=$ http $\% 3 \mathrm{~A} \% 2 \mathrm{~F} \% 2 \mathrm{~F}$.

Torenbeek, M., Jansen, E., \& Hofman, A. (2011). How is the approach to teaching at secondary school related to first year university achievement? School Effectiveness and School Improvement, 22 (4), 351-370.

Tuzlukova, V., Al-Seyabi, S., Al-Rawahi, A., \& Al-Owasi, A. (2014).Reading in the English foundation programs class: Omani students' attitudes, thoughts and selfperceived practices.In Emery, $H$. and Moore, N. (Eds.) Teaching, learning and researching reading in EFL(pp. 70-87). Dubai: TESOL Arabia Publications. 
Wyatt, M. (2012).Issues in supporting the teaching of reading in English as a second language to Arabic speaking children.The Reading Matrix, 12 (2), 146-162.

Yamashita, J. (2004). Reading attitudes in L1 and L2, and their influence on L2 extensive reading.Reading in a Foreign Language, 16 (1). Retrieved May, 5, 2015 from:

http://nflrc.hawaii.edu/rfl/April2004/ya mashita/yamashita.html. 